\title{
Who is Claudia Jones?
}

Julie-Ann McCausland

\section{Introduction}

Claudia Vera Jones née Cumberbatch, was a Trinidad and Tobago-born journalist and activist who, at eight years old, migrated to the United States from Port of Spain, Trinidad, in the British West Indies (Boyce Davies 159). Jones' mother and father had arrived in the United States two years earlier, in 1922, when their economic circumstances had worsened as a result of the drop in the cocoa trade, which had impoverished the West Indies and the entire Caribbean (Boyce Davies 159). Like many Black people who migrated from the West Indies, Jones' parents hoped to find fortunes in the United States, where "gold was to be found on the streets", and the dreams of rearing one's children in a "free America", were said to be realized (Boyce Davies 159). However, the lie of the American dream was soon revealed, as Jones, her three sisters and her parents suffered exploitation and indignity at the hands of the white families and from the legacy of Jim Crow national policy (Boyce Davies 159).

Jones attended Wadleigh High School where she was active in the Junior National Association for the Advancement of Colored People (NAACP). Two years before she graduated high school, Jones' mother died of spinal meningitis at the age of thirty-seven (Boyce Davies xxiv). Later, Jones was committed to Sea View Sanatorium for almost a year after having been diagnosed with tuberculosis (Boyce Davies xxiv). After graduating high school, Jones gained employment in a laundry, a factory, a millinery and in sales (Boyce Davies xxiv). This is significant, because, presumably, her experience from working in these environments contributed to the development of her political thinking. As Carol Bryce notes, Claudia Jones was involved in the Scottsboro Boys' organizing, and she wrote "Claudia's Comments" for a Black newspaper that she subsequently became the editor of (Boyce Davies xxiv). The Scottsboro Boys were nine African American teenagers who were falsely accused in Alabama of raping two white women on a train in 1931. Jones wrote on behalf of the Scottsboro Boys' legal defense as a Journalist for the Young Communist League journal, the "Weekly Review" (McClendon).

In 1936, Jones joined the Communist Party and Young Communist League, where she was assigned to the Youth Movement wing. After several promotions, she eventually became the Educational Director of the Young Communist League, where she was tasked by Party to work with working-class and Black women for peace and equality. It was during this period that she filed preliminary papers for U.S. Citizenship (Boyce Davies xxiv). In 1947, she was arrested for the first time and imprisoned on Ellis Island under the 1918 Immigration Act. This Act stated that the United States would exclude and expel from the country, aliens who were members of the anarchistic and similar classes (Boyce Davies 2008, xxiv). Jones was arrested under this Act because she was not a Citizen of the United States. She was later released on $\$ 1000$ bail and threatened with deportation to her native country of Trinidad if she did not modify her persistent stand against exploitation and the oppression of Black women in the United States (Boyce Davies xxiv). In this period, she toured forty-three U.S. states, covering the west coast, reorganizing statelevel women's commissions, recruiting new party members, and organizing mass rallies. After several arrests at the height of her struggle for the freedom of exploited Black women, and during the McCarthy era, she was declared un-American in 1955 and deported to Britain, as she was considered a subject of the British Empire (Boyce Davies xxiv). 
In London, she was welcomed by friends and Communist Party members, including other communist deportees from the United States. Soon she became affiliated with Caribbean members of the Communist Party of Great Britain (CPGB) (Boyce Davies xxiv). She also joined the West Indian Forum and Committee on Racism and International Affairs and worked in various organizations in London, including the Caribbean Labour Congress (London Branch) (Boyce Davies xxiv). She later founded the West Indian Gazette (later, West Indian Gazette and AfroAsian Caribbean News) in London, was involved in the political organizing of Caribbean, PanAfrican, and third-world communities in London and helped to organize the city's first Caribbean Carnival at St. Pancras Hall. Jones also worked with the African National Congress to organize hunger strikes against apartheid. Additionally, she organized boycotts of South Africa for the freedom of political prisoners such as Nelson Mandela. She met Martin Luther King Jr. in London when he was on his way to Oslo to collect the Nobel Peace Prize and gave a speech in Japan as a delegate to the 10th World Conference against Hydrogen and Atom Bombs (Boyce Davies xxiv). Essentially, Claudia Jones was an influential and popular public figure, an active journalist and public speaker, a close friend of many influential people, including W.E.B. Du Bois, and Amy Ashwood Garvey, who was the female political and intellectual equivalent of C. L. R. James (Boyce Davies 2). ${ }^{1}$

During Jones' years in the United States and Britain, she was vocal in her belief that peace could not be attained if women, especially poor women, were excluded from the conversation. She challenged the Communist Party to take a more serious interest in the cause of Black women (Boyce Davies 40). She died in London, England at the age of 49(Boyce Davies 2008, xxiv). Her funeral drew recognition from people and governments around the world. This recognition included diplomatic representations and media coverage (Boyce Davies 2008, xxiv). Jones' ashes were interred in a plot of land that is located left of the grave of Karl Marx in the Highgate Cemetery, London (Boyce Davies xxiv).

With this background in mind, I focus my discussions in this paper on two themes: a) Claudia Jones' contribution to expanding Marxist thought to incorporate race and gender into its class analysis and b) the impact of her lived experiences in shaping the development of her political thinking. Carol Boyce Davies' biography of Claudia Jones is very strong in that it provides extensive details as to who Claudia Jones was and how instrumental her advocacy was for Black women. However, a weakness I found in the biography is that Boyce Davies did not discuss why Jones' contributions remain largely underappreciated and why Jones remains relatively unknown to many in the Afro-Caribbean culture. I will argue that Claudia Jones' contributions are undervalued because she is constructed as lacking credibility by virtue of being a female. Claudia Jones was a valiant fighter against racism and imperialism who dedicated her life to the progress of socialism and the liberation of Black people.

\section{How has the work of Claudia Jones contributed to expanding Marxist thought to incorporate race and gender into its class analysis?}

Jones was often considered more radical than Marx because she did not believe that capitalism was the only factor contributing to sexism and racism (Edmonds). For Jones, gender was also a significant contributor to the oppression that Black people, and specifically Black women, face in the United States. Marx provided a theory of society in which it would progress through a mode

\footnotetext{
${ }^{1}$ Conspicuously, like Jones, Amy Ashwood Garvey remains outside the pool of knowledge of Caribbean intellectual
} history (Boyce Davies 20082). 
of production and class conflicts between the proletariat, the workers and the bourgeoisie. However, he did not account for race and gender or for the position of Black women in society. Claudia Jones advanced Marx's ideology by expanding it to consider the issues of colonialism, imperialism and an analysis of women in society (Boyce Davies 219). According to Boyce Davies, Jones's position is read by some as being informed largely by Communist Party literature, indoctrination and idealism; however, Jones' position was in part influenced by her vast knowledge of Leninism (Boyce Davies 221). Leninism is derived from the ideology of Vladimir Lenin, a Russian revolutionary, politician and political theorist who had taken a position on what was then called "the woman question," asserting that "we must create a powerful international women's movement, on a clear theoretical basis" (Boyce Davies 3).

Building on Lenin's ideology, Jones supported the creation of a subcommittee within the Communist Party to address the woman question (Boyce Davies 51). She did this by insisting on the development, in the party, of theoretical training for women comrades, the organization of women into mass organizations, daytime classes for women, and "babysitter" funds to allow women's activism. While Boyce Davies did not definitively define the notion of the "the woman question,' I understand from her discussion that the concept refers to the status of women in society and our involvement in feminist movements for social change (Boyce Davies 2008). Nevertheless, though Jones was well read in Leninism and recognized that Lenin had advanced views on the colonial question, she was also cognizant that Lenin spoke only of the enslavement of women within the social and economic structures that restrict them to domestic labour (Boyce Davies 3). Lenin was therefore speaking of a particular type of woman: the white woman. Jones recognized that this general position did not account for the specificities of any group of women, as it spoke of women generally and did not take into consideration that Black women at that time were already located in a super-exploitative condition within the given productive labour sectors (Boyce Davies 3). This is the analytical space in which Claudia Jones began to contribute not only to expanding Marxist thought, but also Leninist thinking, while at the same time providing intellectual leadership from which scholars of Black women's social and political history and condition in various societies could learn and contribute to (Boyce Davies 3).

Claudia Jones' best contribution to Black feminist thought entailed her theorizing of the super-exploitation of the Black woman. The concept rests solidly on Claudia's observation that Black women - " as workers, as Negroes, as women" - were "the most oppressed stratum of the whole population" (Boyce Davies 12). For Jones, "Capitalists exploit woman doubly, both as workers and women. Woman has to face special oppression in every field in capitalist societyas a worker - a wife, a homebuilder and a citizen" (Boyce Davies 40). While most of her theory was put to paper in "An End to the Neglect of the Problems of Negro Women," Jones also wrote on the subject in her column on women's issues for The Daily Worker, titled "Half the World" (Boyce Davies 40). This was a column that made its position clear in its title: in representing women, we are, indeed, representing "half the world" (Boyce Davies 40). Further, Jones' courtroom speech after her sentencing was explicit in making her philosophical and ideological positions clear publicly and officially (Boyce Davies 219). Her speech was not a plea for leniency, but a demonstration that Black women were also thinkers, held ideological positions, and could assert themselves; it was also a demonstration of her work in women's activism and her involvement in a political struggle. She knew she was going to be sentenced but continued to let her voice be heard. She refused to back down from her advocacy (Boyce Davies 219). 
Marx's development of his theory on the mode of production and the working-class is useful for intellectuals who study political thought, but Claudia Jones was someone who worked outside of an academic context, and her entire production of ideas rivaled many of those produced in the universities at the same time (Boyce Davies 10). That is, Claudia Jones' praxis was far more critical, especially for Black people, as she combined theory and practice: she did transformative, "on the ground" work in addition to developing theory. Her intellectual contribution is particularly important since many Black communities did not have access to academic institutions before the civil rights era (Boyce Davies 10). Jones shows, by her example, a way of maintaining her political positions and affiliations and of advancing others beyond Marx's theoretical positionings. She benefitted from Lenin's advances on the issue of imperialism and the national/colonial issue, as well as the woman question (Boyce Davies 67). While being an avowed Marxist-Leninist, she continued to assert the importance of Black women as an analytical category, subject to society's "super-exploitation," but still active, with potential for leadership, and by her example, also thinkers. Her ability to link race, gender, geography and labour in the context of the position of Black women internationally, along with her internationalist, anti-imperialist approach, provided a more advanced reading than Marx of both the conditions of and the possibilities for resistance by Black women under imperialism (Boyce Davies 67).

\section{How did the lived experiences of Claudia Jones shape the development of her political thinking?}

According to Boyce Davies, Claudia Jones' anti-imperialist feminist, socialism stems from her background: Caribbean in geographic and cultural identification and anti-imperialist in orientation. She linked labour to Black identity and women's rights (Boyce Davies 67). Additionally, Claudia Jones' political thinking and activism were also shaped by her affinity to other Black Caribbean feminisms, for example, Elma Francois' feminism. Elma Francois was a political activist from Trinidad and Tobago who, in February 1938, became the first woman in the history of Trinidad and Tobago to be tried for sedition (Boyce Davies 67). According to Boyce Davies, at the trial, "Francois, unlike other defendants, undertook the greater part of her own defence herself" and her speech was very similar to Jones' speech before Judge Dimock, in that the speech revealed a series of internationalist/Pan-Africanist views similar to those that Jones espoused (Boyce Davies 2008, 67). For example, when asked to define "world imperialism and colonialism," Francois "described the relationship between the ruling classes of the world and the exploited workers of the colonies" (Boyce Davies 67). Claudia Jones shared many similar positions on women's activism and involvement in political struggle (Boyce Davies 67). For scholars in the Caribbean, one of the distinctive features of Caribbean feminism is its anti-imperialist, labour orientation, which sees women's economic rights as central to any fulfillment of their human rights in general (Boyce Davies 67). Hence, Jones identifying with Francois might have been central to the development of her thinking and understanding of Caribbean feminism.

Another significant experience of Claudia Jones that shaped the development of her political thinking was her exile from the United States, which she details in the piece titled "Ship's Log," which she wrote for her father aboard the Queen Elizabeth ship (Boyce Davies 157). In this piece, Jones refers to her condition as "my exile for my independent political ideas" and to the United States as the "land I belong to and know and its people with whom I have worked and struggled for social progress" (Boyce Davies 157). In the basic dictionary definition, an exile is one who is separated from his or her own country, often as a result of banishment (Boyce Davies 157). The 
word "deportation" overlaps with "exile" in that it refers to "the lawful expulsion of an undesired alien or other person from a state or [incomplete quote]" (Boyce Davies 157).

Ultimately, Jones turned the pain of being imprisoned and later exiled into a positive emotion, turning the "ship of exile" into a vehicle that would take her to "marvelous places" (Boyce Davies 157). In so doing, she transformed her punishment into an opportunity to carry her activism even further into the diaspora.

\section{Why are her contributions underappreciated today?}

Claudia Jones' contributions to our struggle and the struggles of all oppressed people is one of the most outstanding contributions of a Black Communist. While Jones did not use the word "intersectionality" in her praxis, it is hard not to notice her ideas of equality and intersectionality as she linked race, gender, geography and labour in the context of the situation of Black women internationally (Boyce Davies 67). Jones remains largely unknown, unrecognized and underappreciated today, and she seems to have simply disappeared from major consideration in histories of Black anti-imperialist work and Black transnational feminism. In retrospect, I am reminded of the $19^{\text {th }}$ century political locution, "Ain't I a Woman" by Sojourner Truth, a formerly enslaved Black woman who fundamentally challenged the dominant notions of "woman" and opened a discussion about the concept of intersectionality (Brah and Phoenix 46). Like Jones, Sojourner Truth did not coin or use the term intersectionality, but her discussions of what it means to be a woman under different circumstances has been the subject of many debates, especially as it relates to the concept of global sisterhood (Brah and Phoenix 46). Essentially, like Sojourner Truth, Jones' intellectual contributions have been overlooked from Black History.

I have been thinking of Jones through the concept of the "gender wars" because credibility is such a foundational power in those wars and because women are so often accused of being categorically lacking in this department (Solnit 104). Not uncommonly, when a Black woman says something that impugns a white man or an institution, especially powerful ones, the response often questions not just the facts of her assertion but her capacity to speak and her right to do so (Solnit 104). On this final note, Jones' stunning achievements in the era of men such as Martin Luther King Jr., Normal Manley and Cheddi Jagan, to name a few, paled because she was a woman and one of Caribbean origins; because of this, she continues to be dismissed, erased and silenced. We still exist in a white hegemonic world where Caribbean women and, by extension, Black women and girls are devalued. 


\section{Works Cited}

Brah, Avtar \& Phoenix, Ann. (2004/2013). Supplement 4 - Adapted from Activist Insight: Sojouner Truth (1797-1883). Gender and Women's Studies in Canada: Critical Terrain.

Davies, Carole Boyce. (2008). Left of Karl Marx: The political life of Black communist Claudia Jones. Duke University Press.

McClendon III, J. (2007). Claudia Jones (1915-1964). Retrieved from https://www.Blackpast.org/african-american-history/jones-claudia-1915-1964/

Solnit, Rebecca. (2014). "Cassandra Among the Creeps." (From Men Explain Things To Me. Chicago: Haymarket Books): Harper's Magazine; New York Vol. 329, Iss. 1973. 4-9. 